ДяГИЛЕВ Василий Васильевич - кандидат исторических наук, доцент; доцент департамента социологии, истории и философии Финансового университета при Правительстве РФ (125993, Россия, г. Москва, Ленинградский пр-кт, 49; VVDyagilev@fa.ru)

ШЕВЧЕНКО Ольга Викторовна - кандидат философских наук, доцент департамента соииологии, истории и философии Финансового университета при Правительстве РФ (125993, Россия, г. Москва, Ленинградский пр-кт, 49; Shevchenkoo@inbox.ru)

\title{
ГЛОБАЛИЗМ И НАЦИОНАЛЬНАЯ ИДЕОЛОГИЯ
}

Аннотация. Статья посвящена проблемам глобализации в свете ее противостояния национальной идеологии и национальным ценностям. В работе анализируется возможность существования так называемых общечеловеческих ценностей, возможность их совмещения и сосуществования с ценностями традиционными и национальными. В статье делается вывод, что обоснование вмешательства в дела других государств защитой демократических ценностей привело не только к ухудшению уровня жизни этих государств, но и к отрицанию самой идеи демократии, а также что столкновение цивилизаций и идеологическое сближение - явления временные и взаимно обусловленные, хотя и разнонаправленные. Ключевые слова: глобализация, идеология, проблемы социально-экономического развития, ТНК, цивилизация

Можно опровергнуть известное суждение, показать его условность: но этим не уничтожается потребность в таком суждении. Ложные ценности невозможно искоренить при помощи аргументов: совершенно так же, как и искаженную оптику в глазу больного. Нужно понять необходимость их существования - они суть следствия причин, которые не имеют ничего общего с доводами.

Ф.В. Ницие

$\Pi^{2}$ осле крушения СССР идеи о «конце истории», унификации культурного пространства с нарастающей популярностью стали распространяться в научной и околонаучной сферах. Выдающиеся ученые прошлого (например, Н.Я. Данилевский) считали, что культурные типы не передаются и не наследуются, но в конце прошлого века большую роль стали играть и огромное влияние приобрели теории о неизбежности создания единой человеческой цивилизации, ядром которой будут общечеловеческие ценности.

Отрицать сегодня существование процессов глобализации не представляется возможным. Хотя даже определения понятия «глобализация» имеют качественные, существенные различия, не говоря уже о том, что нет никаких методик измерения процессов глобализации. По всей видимости, глобализацией оказались прежде всего затронуты информационные и коммуникационные каналы, посредством которых осуществляется постоянное давление на массовое сознание. В культурных же аспектах влияние идей глобализма не является скольконибудь значительным - по сути дела, основное распространение данные идеи имеют в англосаксонском социуме и в зонах его влияния.

Довольно сложным и противоречивым является само понятие «общечеловеческие ценности». Возможно ли, даже в теоретическом аспекте, выделять надсоциальные феномены, которые нельзя конкретизировать в традиции данного локального сообщества? Могут ли ценности разделяться всеми индивидами? Возможно ли перестроить социальную и личностную иерархию ценностей? На все данные вопросы с научной точки зрения нужно дать отрицательные ответы.

К сожалению, следует констатировать, что влияние процессов глобализации на социально-экономические аспекты жизни общества исследовано довольно поверхностно, без аргументированного анализа и выводов. 
В работе доктора философских наук О.Н. Яницкого «Глобализация: от теории к измерению» важнейшим индикатором глобализации названа стабильность жизни на планете. Под данным термином он понимает следующее: «стабильность жизни на планете - важнейший индикатор глобализации... Чем меньше разрыв между бедностью и богатством, чем меньше войн и вооруженных конфликтов... чем менее человек будет вмешиваться в природные экосистемы, тем устойчивее будет глобальный социум... здоровье и благосостояние населения» [Яницкий 2018: 167].

С данной точкой зрения можно было бы согласиться, но тогда возникают вопросы к конкретным достигнутым результатам глобализации. И данные результаты не могут не вызывать опасений. Наверное, со времен Карибского кризиса наш мир не был так близок к ядерной войне, как теперь. Число вооруженных конфликтов в странах Азии, Африки (в перспективе - и в Латинской Америке) постоянно возрастает; дифференциация населения, особенно в нашей стране, достигла критических пределов. Неблагополучно обстоят дела и с экологическими проблемами.

Если говорить об истоках идеологии глобализма, то основание ее коренится в концепции свободного рынка - финансового капитализма, государственные границы, национальная идеология являются препятствием на пути финансовых потоков. Денежный капитализм по самой своей сути космополитичен: для получения прибыли хороши любой антураж и любая почва. Следовательно, необходимо было противопоставить национальным интересам предельную абстракцию, подобную общечеловеческим ценностям. К абстрактным, оторванным от конкретных условий положениям трудно подойти с позиций рациональной критики. В данной связи представляется весьма целесообразным устранить подобную критику в принципе. Для этого крайне желательно снизить интеллектуальный потенциал общества в самом широком толковании последнего. Нужны исполнители и потребители, а не идеологи и инициаторы. Все решено для отдельного индивида - круг его потребностей, культурные запросы, цели деятельности. Все направлено на решение проблемы извлечения дополнительной прибыли. За политикой и пропагандой глобализма стоят серьезнейшие финансовые круги - в этом сила данной идеологии. Противостоять ей сегодня попросту невыгодно для многих политических структур - органов власти на различных уровнях.

Если корни идеологии глобализма - в экономике, то тактические устремления и задачи - в области политики. Нельзя добиться решения экономических целей в современном мире без поддержки власти на локальном, региональном и международном уровне. Но при таком раскладе социальные вопросы уходят на второй план - цели общественного развития зачастую попросту не согласуются с интересами финансовых кругов. Реальная задача государственной идеологии заключается в создании программы социального развития нации, выявлении приоритетных интересов общества, расчете возможностей их (интересов) воплощения в реальную практику.

По всей видимости, идеология, которая осуществляется с применением силы и подавлением инакомыслия, не может быть прочной. Подтверждение этому итоги Арабской весны, приведшие не к демократизации, а к росту экстремизма и религиозного фанатизма.

Ситуация усугубляется и нарастанием кризисных явлений, связанных с усилением глобализации в финансовой сфере. Как показал опыт 2008 г., негативные показатели в ведущих банковских системах приводят к общемировому кризису. Глобализм привел мировую финансовую сферу к такому положению, когда большинство государств живут за счет кредитов, имея при этом значи- 
тельные долговые обязательства. Об этом сейчас говорят многие серьезные ученые [Катасонов 2014].

В данных условиях большую роль будет играть социальное самоопределение государств, выработка ими устойчивых целей развития, средств их достижения. Это задача идеологии, которая должна быть рационально обоснованной, учитывать политические, экономические и социальные аспекты развития. К сожалению, в Конституции РФ указано, что «в Российской Федерации признается идеологическое многообразие. Никакая идеология не может устанавливаться в качестве государственной или обязательной» 1 .

В связи с этим нынешнее понимание глобализма не может вести даже к относительной стабильности в мире. Возрастание дифференциации населения в мире неизбежно приведет к возникновению новых конфликтов, которые, по всей вероятности, будут носить глобальный характер.

Неразрывная связь между экономикой, политикой и социальной сферой приводит к тому, что без осознания реальных целей государственной деятельности утрачивается национальный суверенитет. В условиях, когда господствует плюрализм идеологий, основная масса населения утрачивает реальное понимание ситуации, становится игрушкой в руках профессиональных пропагандистов. Манипулирование общественным мнением легко осуществляется теми силами, которые имеют для этого финансовые возможности. Поэтому нет ничего удивительного в том, что силы, еще недавно считавшиеся оплотом демократии, открыто выступают против свободы средств массовой информации, да и так называемые фейковые новости являются оборотной стороной данного процесса.

Национальные идеи западного мира сегодня не имеют прочного обоснования, если не принимать за таковой возрожденный небольшими партиями национализм правого толка. Но это идеология не сегодняшнего, а вчерашнего (может быть, даже позавчерашнего) дня. Они зовут в прошлое, а не в будущее. Современная же, широко распространенная в западном социуме идеология толерантности неизбежно и закономерно испытывает серьезнейший кризис. Толерантностью нельзя построить базисные нормы идеологии, потому что в своей нынешней интерпретации - это безнравственное и непременно ведущее к упадку течение мысли. Терпимость и сочувствие к ошибкам и заблуждениям если не естественны, то вполне допустимы. Но терпимость к нарушениям нравственных устоев, к разбою, грабежу, коррупции - свидетельство умирающей цивилизации. Нельзя быть толерантным к разрушению собственного социума - это национальное самоубийство. Возможно, процесс саморазрушения романо-германской цивилизации сегодня уже принял необратимый характер. Об этом свидетельствовали мыслители прошлого и даже позапрошлого века.

Национальная идея не может опираться на абстракции, которые нельзя воплотить в жизнь с пользой для социума. Европейская идеологическая мысль конца прошлого - начала нынешнего веков ничего, способного вызвать тенденции самосовершенствования общественной жизни, создать не смогла. В последнее десятилетие наметились конфронтационные столкновения между странами «старой» Европы, значительно ухудшились отношения с Российской Федерацией. И дело здесь даже не в санкционном давлении - нет точек соприкосновения в понимании будущего Европы. Можно с горечью отметить, что нет базиса для межцивилизационного диалога. Да и события во Франции конца 2018 - начала 2019 г. показали не только наличие экономических про-

\footnotetext{
1 Конституция Российской Федерации. 1993. Ст. 13. Доступ: http://www.consultant.ru/document/ cons_doc_LAW_28399/
} 
блем у населения страны, но и отсутствие долгосрочной социально-политической программы, способной сплотить граждан и подвигнуть их на созидательные действия. Национальная идеология должна выступить объединительной силой, и если во Франции перспективы выглядят довольно туманными, то в нашей стране при высоком рейтинге доверия президенту все выглядит не столь пессимистично. При этом нет и острой необходимости вносить коррективы в Конституцию РФ. Идеологические прерогативы развития отечественного социума можно обозначить в рамках программы ближайшего социально-экономического развития России.

Не только признание, но даже широкое распространение идеологии, препятствующей национальному развитию, может привести к крайне негативным последствиям. Сегодня необходимо признать, что идеология глобализма в том виде, в котором она существует, враждебна национальным интересам большинства стран мира (нашу же страну в этом перечне следует выделить особо). Критика идеи глобализации важна и необходима, но при этом необходимо помнить, что данная критика не должна перерастать в национализм, шовинизм в отторжение другой цивилизации. Национальная идеология, признавая приоритеты собственного развития, не должна ставить преграды для развития других, препятствовать межкультурным коммуникациям. Честное признание своих интересов позволяет лучше организовать цивилизационный диалог, создать перспективы и определить направления дальнейшего сотрудничества.

Какое же будущее у глобализации? Социальные тенденции на цивилизационное сближение и на размежевание, по-видимому, естественным образом сменяют друг друга. Столкновение цивилизаций и идеологическое сближение - явления временные и взаимно обусловленные, хотя и разнонаправленные. С позиций строгой науки ни то ни другое социальное явление нельзя назвать позитивным или негативным - они естественны.

Совсем по-другому обстоят дела с так называемой ценностной, или идеологической глобализацией.

Навязывание чужих и чуждых интересов не может привести ни к чему позитивному. Обострение современной обстановки, «планетарные кризисные явления» - явные свидетельства отказа от национальных идеологий в пользу тупикового «конца истории» и пропаганды общих, глобальных ценностей. А к чему приводят данные «ценности», мы уже говорили выше.

Но может быть, сегодня государственная идеология является пережитком прошлого? Может быть, ее время безвозвратно ушло? Нам представляется, что на данные вопросы следует дать отрицательные ответы. Пока существуют государства и нации, будут существовать государственные и национальные интересы. Согласовывать эти интересы на международном уровне, безусловно, необходимо. Но также очевидно, что приоритет при этом должен отдаваться интересам национальным. Попытки облагодетельствовать все человечество благородны и заслуживают всяческого уважения. Но начинать нужно с достижимого и конкретного, от локального переходить к глобальному. Движение обратное - от глобального к локальному, по всей видимости, ни к каким результатам привести не может - это либо обман, либо самообман. ТНК в современном мире невыгодно существование национальных экономик в их классическом понимании, поэтому у абстрактной идеи глобализма есть постоянное мощное лобби. Глобализм для данных компаний - это непременное условие жизни и процветания, получение новых рынков сбыта. Для них, при всей абстрактности идеологического обоснования, существование наднациональных структур и институтов является залогом получения прибыли и борьбы с конкурентами. События недалекого прошлого - избрание президентом США республиканца 
Д. Трампа -дополнительное тому подтверждение. Казалось бы, позиция поддержки национальной экономики должна была вызвать всеобщее одобрение не только со стороны простых граждан, но и самых широких общественных кругов. Мы же видим ситуацию, когда президент США подвергается нападкам не только со стороны СМИ, но его деятельность не одобряется ни в конгрессе, ни со стороны многих общественных организаций.

Но не только страны мировой периферии испытывают сегодня давление со стороны ТНК. Даже США сегодня вынуждены поступаться национальными интересами в угоду корпорациям. Вывод производственных мощностей за пределы страны подрывает не столько экономику, сколько саму структуру общества.

Подводя итоги, хотелось бы отметить, что неизбежное крушение однополярного мира ведет не только к ужесточению идеологического противоборства, но и к формированию специфических национальных проектов. Для России национальная идеология является жизнеутверждающей программой. Она должна базироваться на продуманной системе социально-экономического развития, ставить цели и задачи конкретного улучшения уровня жизни российского общества. Глобализация естественная, в рамках межкультурного диалога, заслуживает анализа, оценки и эмпирической систематизации. Глобализация как идеологическое учение, направленное на создание безальтернативного, тоталитарно управляемого, лишенного ценностных ориентиров социума, ведет нас к созданию таких условий, когда под угрозой будет само выживание человечества.

\title{
Список литературы
}

Катасонов В.Ю. 2014. О проценте: ссудном, подсудном, безрассудном. «Денежная иивилизация» и современный кризис. М.: Кислород. 704 с.

Яницкий О.Н. 2018. Глобализация: от теории к измерению. - Россия реформирующаяся: ежегодник. Вып. 16. М.: Новый хронограф. С. 145-170.

DYAGILEV Vasiliy Vasil'evich, Cand.Sci. (Hist.), Associate Professor; Associate Professor of the Department of Sociology, History and Philosophy, Financial University under the Government of the Russian Federation (49 Leningradsky Ave, Moscow, GSP-3, Russia, 125993; VVDyagilev@fa.ru)

SHEVCHENKO Olga Viktorovna, Cand.Sci. (Philos.), Associate Professor of the Department of Sociology, History and Philosophy, Financial University under the Government of the Russian Federation (49 Leningradsky Ave, Moscow, GSP-3, Russia, 125993; Shevchenkoo@inbox.ru)

\section{GLOBALISM AND NATIONAL IDEOLOGY}

\begin{abstract}
The article is devoted to the problems of globalization in the light of its opposition to the national ideology and national values. The paper analyzes the possibility of the existence of so-called universal values, the possibility of their combination and coexistence with traditional and national ones. The article concludes that the justification of interference in the affairs of other states by the protection of democratic values led not only to a deterioration in the living standards of these states, but also to the denial of the very idea of democracy. In modern conditions of economic and, above all, financial globalization, the social self-determination of states will play a big role, as well as elaboration of sustainable development goals and means to achieve them. This is the task of ideology, which must be rationally substantiated before its concrete implementation. The work points out that the very concept of globalization is often interpreted in quite different ways; there is no scientific approach to its measurement. The national idea cannot base on abstractions that cannot be put into practice for the benefit of society. The paper concludes that the clash of civilizations and the ideological convergence are temporary phenomena and mutually determined, although multidirectional ones.
\end{abstract}

Keywords: globalization, problems of socio-economic development, civilization, transnational corporations 